\title{
Estimation of gamma globulin in the serum of patients with hypogammaglobulinaemia
}

\author{
R. A. KEKWICK, L. VAllet, M. CUTBUSh, P. L. MOLlison, \\ A. R. THOMAS, P. G. H. GELL, AND J. F. SOOTHILL \\ From the Lister Institute of Preventive Medicine, London, the M.R.C. Blood Transfusion \\ Research Unit, Postgraduate Medical School of London, and the Department \\ of Experimental Pathology, Birmingham University Medical School
}

SYNOPSIS Three methods of estimating $\gamma$ globulin in the serum of patients with hypogammaglobulinaemia are described and compared, namely free electrophoresis, the inhibition of anti- $\circ$ globulin antiserum method, and the gel diffusion precipitin method. Data from 142 parallel estimations are reported.

The errors of these methods are determined.

The results of the three techniques give good general agreement. This is due to the fact that the 7S component dominates the estimations whichever technique is used. Some discrepancies are $\underset{\mathbb{\Phi}}{\mathbb{Z}}$ discussed.

All of the techniques are applicable to the diagnosis of hypogammaglobulinaemia. Their practical $\stackrel{\oplus}{\mathscr{C}}$ limitations are discussed.

In 1956, at the request of the Ministry of Health, the Medical Research Council established a working party to study hypogammaglobulinaemia, to organize the supply of $\gamma$ globulin to patients with this condition in the United Kingdom, and to observe the effect of treatment. One of the criteria accepted for diagnosis was that the serum $\gamma$ globulin concentration should be less than $200 \mathrm{mg} . / 100 \mathrm{ml}$. (less than $100 \mathrm{mg} . / 100 \mathrm{ml}$. for infants under 6 months old). To establish this and to observe the effect of the $\gamma$ globulin injections on the serum $\gamma$ globulin concentration of treated patients, three different laboratories made estimations of $\gamma$ globulin by three different techniques. At the Lister Institute free electrophoresis was used, at the M.R.C. Blood Transfusion Research Unit the inhibition of antiglobulin serum, and at Birmingham University Medical School the gel diffusion precipitin technique.

The detailed techniques and the results of these estimations are reported here; we discuss the identity of the proteins estimated by the electrophoretic and the immunological techniques, the relative errors of these techniques, and their application to the diagnosis of hypogammaglobulinaemia.

Received for publication 1 February 1961.

\section{METHODS}

Venous blood was collected by the physician in charge of the patient, and samples of the separated serum were sent $\overline{0}$ to us by post. Since many of the patients suspected of 3 having hypogammaglobulinaemia were children, the volume of serum was often small, and it was not always? possible to estimate the $\gamma$ globulin by all three techniques. We therefore report the results obtained on those sera? which were tested by more than one technique.

ELECTROPHORESIS An accurately measured volume of serum, usually $4.0 \mathrm{ml}$., was pipetted into a cellophane membrane, and dialysed at $2^{\circ} \mathrm{C}$. for a period of three days $\mathrm{O}$ against 10 vol. of phosphate buffer $(p H 8.0$, I 0.2 ; $\mathrm{Na}_{2} \mathrm{HPO}_{4} \mathbf{0 . 3 2 6} \mathrm{M}, \mathrm{KH}_{2} \mathrm{PO}_{4} \mathbf{0 . 0 2 2} \mathrm{M}$ ), the buffer beingo changed six times during the course of the dialysis.

The dialysed serum was made up quantitatively with $N$ buffer to $10.0 \mathrm{ml}$. in a volumetric flask and the solution was cleared either by centrifuging, or, if very turbid, by passing through a clarifying filter in a centrifugal Seitz filter (M.S.E. Ltd.). The refractive index of the buffero $\left(\mathrm{N}_{0}\right)$ and of the serum protein solution $\left(\mathrm{N}_{1}\right)$ was determined at $25 \cdot 0^{\circ} \mathrm{C}$. with a dipping refractometer, using light $\frac{C}{\square}$ of wavelength $546 \mathrm{~m} \mu$. isolated from a mercury arc with a s suitable light filter. From the refractive index difference $N_{1}-N_{0}$ the refractive increment $N_{s}$ of the total protein $-\frac{0}{0}$ in the undiluted serum was calculated by multiplying by the appropriate dilution factor.

For electrophoresis, the dialysed serum protein solution 
was diluted with buffer to a refractive increment of 0.00350 . It was subjected to electrophoresis in the long centre section cell type of Tiselius U-tube in a bath at 0.0 to $0.2^{\circ} \mathrm{C}$. The potential applied was adjusted to give a current of $10.0 \mathrm{~mA}$ for the first hour of electrophoresis and then was increased to $15 \mathrm{~mA}$ and maintained at this level for a further three hours.

The diagonal Schlieren optical system (Philpot, 1938) was used to follow the course of electrophoresis and photographs were taken on Ilford half tone panchromatic plates with light of wavelength $546 \mathrm{~m} \mu$ isolated from a mercury arc by a suitable filter.

The final pair of photographs obtained from the anode and cathode limbs of the U-tube after four hours of electrophoresis was projected with an optical enlargement of eight diameters onto graph paper and the curves drawn in. The curves were analysed geometrically by reflection and the areas corresponding with the individual components measured with a planimeter. From the results obtained the composition of the serum was calculated in terms of the percentage of tha total refractive increment attributable to each component, taking the average of the values derived from the anode and cathode curves.

The refractive increment of the $\gamma$ globulin in the serum is given by $\mathrm{N}_{s} \times \mathrm{G} \times 10^{-2}$ (where $\mathrm{G}$ is the percentage of $\mathrm{N}_{\mathrm{s}}$ attributed to $\gamma$ globulin). This value is converted in $\mathrm{mg} . / 100 \mathrm{ml}$. by dividing by 0.00189 , the specific refractive increment of $\gamma$ globulin (Perlmann and Longsworth, 1948) and multiplying by 1,000 . Therefore the $\gamma$ globulin concentration is given by:-

$$
\frac{\mathrm{N}_{\mathrm{s}} \times \mathrm{G} \times 10}{0.00189} \mathrm{mg} . / 100 \mathrm{ml} \text {. }
$$

INHIBITION OF ANTIGLOBULIN SERUM The principle of this method is that $\gamma$ globulin inhibits the reaction between an antihuman $\gamma$ globulin serum and red cells sensitized with incomplete Rh-antibody (Coombs and Mourant, 1947). Very small amounts of globulin will inhibit the reaction (Wiener, Hyman, and Handman, 1949), and thus a test can be devised to estimate the serum $\gamma$ globulin concentration in cases of hypogammaglobulinaemia (Wiener, 1955; Grubb, 1956; Mollison, 1956).

The technique used in this work was essentially that described previously (Mollison, 1956).

As a standard, a large sample of serum was obtained from a normal donor and stored at $-20^{\circ} \mathrm{C}$. Aliquots of this serum were thawed from time to time and a 1 in 2,000 dilution prepared by pipetting $0.5 \mathrm{ml}$. of serum with an Ostwald pipette into $1,000 \mathrm{ml}$. of saline. From this diluted serum, further dilutions of 1 in $3,000,1$ in $4,000,1$ in $5,000,1$ in $6,000,1$ in $7,000,1$ in $8,000,1$ in 9,000 , and 1 in 10,000 were prepared, using relatively large volumes to minimize errors (e.g., $5 \mathrm{ml}$. of 1 in 2,000 $+5 \mathrm{ml}$. of saline to prepare a 1 in 4,000 dilution). The diluted sera were kept at $+4^{\circ} \mathrm{C}$. for not more than three months. (Sodium azide at a final concentration of 1 in 1,000 was added to the diluted sera to prevent the multiplication of bacteria.)

Red cells coated with $\gamma$ globulin were prepared by incubating $\mathrm{Rh}$-positive red cells for an hour with a serum containing incomplete anti-R $\mathrm{h}$, and then washing the cells three times in large volumes of a $1 \%$ saline solution. The same anti-Rh serum was used throughout the investigation.

Several different antiglobulin sera (prepared in rabbits) were used, but the dilution chosen for a particular estimation was always one which gave only moderately strong agglutination with the Rh-sensitized cells.

Serum from a suspected case of hypogammaglobulinaemia was tested as follows: the patient's serum was diluted in $1 \%$ saline to give concentrations of 1 in 50 , 1 in 200,1 in 800,1 in 1,600,1 in 3,200, and 1 in 6,400. One volume of diluted antiglobulin serum was placed in each of seven tubes and an equal volume of the 1 in 50 dilution of the patient's serum was added to the first tube; an equal volume of the 1 in 200 dilution was then added to the second tube, and this procedure was continued to provide seven mixtures containing a constant concentration of antiglobulin serum and decreasing concentrations of the patient's serum. A similar series of mixtures was prepared using the nine dilutions $(1 / 2,000$ up to $1 / 10,000$ ) of the standard serum.

After 10 minutes, one drop from each mixture of the test series and of the standard series was placed in a separate square on a large opal glass tile. One drop of a $20 \%$ suspension of sensitized cells was added to each, and, after two minutes, and again after five minutes the strength of agglutination in each square was noted. The highest dilution of human serum giving a definite inhibition of the agglutination in each series was taken as the end-point.

Thus, if the end-point of the standard serum (which contained $1,200 \mathrm{mg}$. $\gamma$ globulin per $100 \mathrm{ml}$.) was a dilution of 1 in 4,000, and that of the test serum was 1 in 50, the concentration of $\gamma$ globulin in the test serum would be very approximately

$$
\frac{50}{4,000} \times 1,200=15 \mathrm{mg} . / 100 \mathrm{ml}
$$

After this preliminary test had been made, fuither dilutions of the test serum were prepared to define the $\gamma$ globulin content more precisely. For convenience, these dilutions were prepared in an arbitrary series, e.g., 1 in 200,1 in 300,1 in 400,1 in 500,1 in 600,1 in 700 , and 1 in 800 . The difference between successive dilutions varied from about $15 \%$ to $50 \%$. It was often possible to decide that the end-point fell hetween two dilutions; for example, the inhibition produced by a 1 in 600 dilution of test serum might be obviously greater than that produced by $a$ in 10,000 dilution of standard serum, whereas the inhibition produced by a 1 in 700 dilution of test serum might be obviously less. It would then be concluded that a 1 in 650 dilution of the test serum was equivalent to a 1 in 10,000 dilution of the standard serum in its ability to inhibit the reaction.

In reading the end-point, a series of comparisons was always made. For example, the dilutions of test serum and standard serum giving slight inhibition were noted and those giving almost total inhibition were noted. In this way, two or more estimates of the value were obtained, and the result was given as the mean of these values. It was found that the method could be made more sensitive by taking readings after the sensitized cells and anti- 
globulin serum had been allowed to react for only about two minutes.

The $\gamma$ globulin content of the standard serum was estimated at the beginning of the present work by free electrophoresis (Tiselius apparatus); the serum was found to contain $14.8 \% \gamma$ globulin (mean of ascending and descending boundaries); the total serum protein concentration was $7.8 \mathrm{~g} . / 100 \mathrm{ml}$. and the $\gamma$ globulin content of the serum was therefore estimated at $1,155 \mathrm{mg} . / 100 \mathrm{ml}$. After the serum had been stored for three years a second estimate was made by free electrophoresis (PerkinsElmers instrument). The serum protein was found to contain $13.8 \%$ of $\gamma$ globulin, a result in reasonable agreement with the first estimate. Results reported were based on the first (Tiselius) estimate of the standard.

GEL DIFFUSION PRECIPITIN The method, described by Gell (1957), entails visual matching of patterns of precipitate produced when suitable dilutions of unknown serum and a standard are allowed to react with a series of dilutions of a specific rabbit anti-human $\gamma$ globulin antiserum, in agar gel.

Preparation of antiserum Sandy lop (M.R.C. strain) rabbits were immunized with purified $\gamma$ globulin (fraction G3 of Kekwick and Mackay, 1954), kindly supplied by the Blood Products Laboratory, the Lister Institute, Elstree. A mixture of equal volumes of Freund's adjuvant (Freund and McDermott, 1942) and of a $1 \mathrm{~g} . / 100 \mathrm{ml}$. solution of $\gamma$ globulin was emulsified and $1 \mathrm{ml}$. was injected subcutaneously at two different sites on both the first and the fourteenth day of the course. On the twentyeighth day $0.5 \mathrm{ml}$. of the $1 \% \gamma$ globulin solution was injected intraperitoneally, and on alternate days thereafter increasing volumes up to $1 \mathrm{ml} .(0 \cdot 2,0 \cdot 5,0 \cdot 75,1,1,1 \mathrm{ml}$., etc.) of the $\gamma$ globulin solution was injected intravenously until the rabbits became dyspnoeic a few minutes after the injection. Five days after the last injection 60 to $80 \mathrm{ml}$. of blood was taken from the marginal ear vein. Rabbits which produced a satisfactory antiserum were reinjected every six months, using the intraperitoneal and intravenous course only.

The antisera were assessed by immunoelectrophoresis. There were a few weak contaminating antibodies in most of the antisera but, as the anti- $\gamma$ globulin antibody was very strong, these did not produce lines of precipitation at the dilutions used for the estimations. As shown in Fig. 1, only one line of precipitation was seen when such a diluted antiserum interacted with serum from a patient with hypogammaglobulinaemia.

The standard was a preparation of purified $\gamma$ globulin (fraction G3, see above) supplied by the Lister Institute, containing $8.4 \mathrm{~g} . / 100 \mathrm{ml}$. of $\gamma$ globulin, as estimated by electrophoresis and the micro-Kjeldahl method. It was stored frozen in divided portions and was diluted to 1 g. $/ 100 \mathrm{ml}$. when required for use.

Davis New Zealand agar was dissolved in $p \mathrm{H} \mathrm{7.4}$ phosphate buffer saline $\left(\mathrm{K}_{2} \mathrm{HPO}_{4} 2.75 \%, \mathrm{KOH} 0.8 \%\right.$, $\mathrm{NaCl} 1.7 \%$, containing $1 / 10,000$ sodium azide, by immersion in a boiling water bath for two hours, filtered through boiled filter paper pulp by suction, and $8 \mathrm{ml}$. poured into each flat Petri dish, $6.7 \mathrm{~cm}$. internal diameter (depth of agar about $2.5 \mathrm{~mm}$.). When the agar had set, a

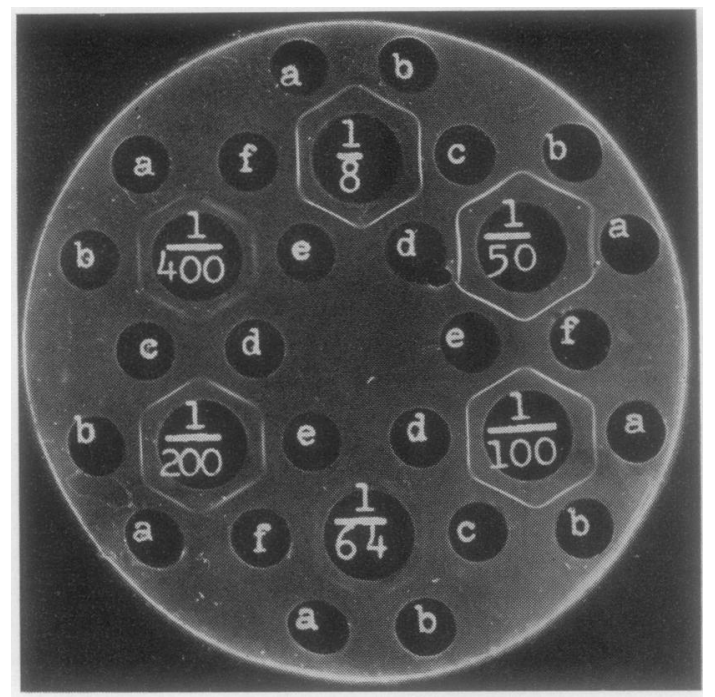

FIG. 1. Agar plate for gel diffusion precipitin technique.

pattern of six large holes, each surrounded by six small holes (as illustrated in Fig. 1) was cut by a special cutter which removed the agar plugs by suction.

Dilutions were made by counting drops from a Pasteur pipette and a single drop of each dilution of antigen or antibody was placed in each hole in the agar plate. Dilutions of $1 / 50,1 / 100,1 / 200$, and $1 / 400$ of the standard $1 \% \gamma$ globulin were placed in four of the large holes, as shown in Fig. 1. Dilutions of the unknown serum of $1 / 8$, and 1/64 were placed in the other two large holes (see Fig. 1). When the $\gamma$ globulin content was very low, the estimation was repeated, using eight drops and one drop respectively of undiluted serum.

Six stock logarithmic dilutions of the antiserum were made. These varied with the antiserum, but a suitable series for a strong antiserum would be $1 / 8,1 / 11,1 / 15$, $1 / 20,1 / 26,1 / 33$. Single drops of these dilutions were placed in the small holes surrounding the antigen containing holes (marked a to $\mathrm{f}$ on Fig. 1). As shown in Fig. 1, each 'antigen hole' was surrounded by an identical 윽 series of six 'antibody holes' (though for economy's $>$ sake, the higher antiserum concentrations were shared by two antigen holes so that consecutive antigen holes were surrounded by a mirror image arrangement of antibody $\Omega$ dilutions).

The Petri dish was covered, and left at room temperature for about 16 hours, while diffusion and precipitation $\omega$ occurred. A hexagon of precipitation developed around $\bar{x}$ each antigen hole, the appearance of which depended 0 solely on the concentration of $\gamma$ globulin in the hole. It $\frac{\bar{D}}{\mathrm{D}}$ will be seen in Fig. 1 that the pattern of the precipitation around each of the 'standard holes' was clearly different $\square$ from the others, that around the holes containing the $\bar{D}$ higher $\gamma$ globulin concentrations being nearer the anti- $\vec{\Phi}$ body holes, and that around the lower concentrations $\frac{O}{D}$ being nearer the antigen hole. The lines also showed a $\varrho$ 
characteristic appearance at different concentrations, being either well defined and narrow at optimal proportions, or diffuse in antigen or antibody excess. The pattern around the holes containing the unknown serum could be matched line by line with those around the holes containing the standard. In Fig. 1, a 1/8 dilution of a hypogammaglobulinaemia serum matched precisely the $1 / 100$ dilution of the $1 \mathrm{~g} . / 100 \mathrm{ml}$. standard, i.e., $10 \mathrm{mg}$./ $100 \mathrm{ml}$. The $1 / 64$ dilution of the unknown was correspondingly weaker than the $1 / 400$ standard. Therefore the serum contained $8 \times 10=80 \mathrm{mg} . / 100 \mathrm{ml}$. Such direct matches in this plate would give readings of $20,40,80$, $160,320,640$, and $1,280 \mathrm{mg}$. $100 \mathrm{ml}$. By using one drop and eight drops of undiluted serum, this series could be continued down to $0.3 \mathrm{mg}$. $/ 100 \mathrm{ml}$. Interpolations could also be made, when the unknown appeared midway between two standards, or rather nearer one or another. Results of such interpolations were expressed as arithmetic intermediate steps, e.g., 20, 25, 30, 35, 40, 50,60, $70,80,100 \mathrm{mg} . / 100 \mathrm{ml}$. etc. (the direct matches are in italics).

\section{RESULTS}

The results of estimations of $\gamma$ globulin in 142 serum specimens are represented graphically in Fig. 2. These include all samples submitted for diagnostic purposes, and subsequent samples obtained during the course of treatment from 35 patients in whom the diagnosis was confirmed. A wide range of $\gamma$ globulin concentrations was measured, from less than $1 \mathrm{mg}$. to nearly $2 \mathrm{~g} . / 100 \mathrm{ml}$. The higher figures were obtained from suspects in whom the diagnosis was not confirmed, and from treated cases. All specimens were estimated by the gel diffusion precipitin method, but only some of them by the other two methods. The points representing specimens estimated by all three techniques are plotted in closed circles, and those estimated by only two by open circles.

There is an obvious positive correlation between each set of results, and the points appear reasonably consistent with the $45^{\circ}$ line marked on each graph. The two graphs which include the gel diffusion precipitin results have a large scatter at higher values, as would be expected from a titration technique using a geometric scale of dilutions. The two graphs, which include the electrophoresis results, have a larger scatter at the lower levels (below about $300 \mathrm{mg}$. $/ 100 \mathrm{ml}$.), as compared with the plot of the two immunological techniques which precisely approaches the origin.

DETERMINATION OF ERRORS OF TECHNIQUES The error of each technique was estimated. A series of five dilutions of normal human serum was made, using hypogammaglobulinaemia serum as diluent, so that they covered most of the range of the unknown sera.
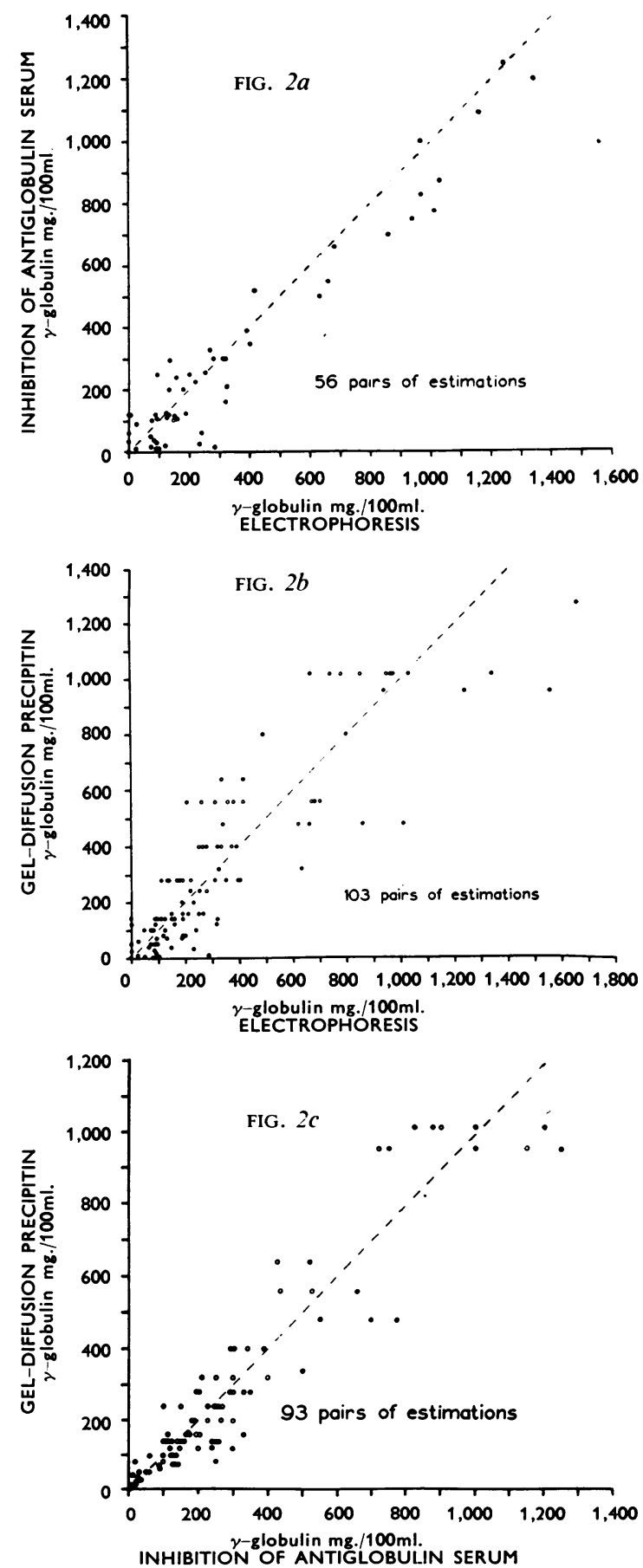

FIG. 2. Plots of the estimations of $\gamma$ globulin in the serum from the patients suspected of, or under treatment for, hypogammaglobulinaemia by each of the three techniques used. The dotted line is drawn at $45^{\circ}$. 
Each was estimated five times by each of the two immunological techniques. The results are given in Table I. For the gel diffusion precipitin technique,

\section{TABLE I}

RESULTS OF EXPERIMENTS TO DETERMINE ERRORS OF TWO IMMUNOLOGICAL TECHNIQUES FOR ESTIMATING SERUM $\gamma$ GLOBULIN OVER A WIDE RANGE OF $\gamma$ GLOBULIN CONCENTRATIONS

\begin{tabular}{llcc} 
Method & $\begin{array}{l}\text { Mean } \\
\text { Concentration } \\
\text { (mg./100 ml.) } \\
\text { (Five } \\
\text { Determinations) }\end{array}$ & $\begin{array}{l}\text { Standard } \\
\text { Error } \\
(\mathrm{mg} . / 100 \mathrm{ml} .)\end{array}$ & $\begin{array}{l}\text { Coefficient } \\
\text { of } \\
\text { Variation } \\
(\%)\end{array}$ \\
\hline Gel diffusion precipitin & 1,120 & 63 & 14 \\
& 496 & 28 & 13 \\
& 144 & 8 & 12 \\
Inhibition of anti- & 44 & $2 \cdot 5$ & 12 \\
globulin serum & 8.4 & 0.5 & 11 \\
& 2,174 & 128 & 8 \\
& 1,012 & 59 & 6 \\
& 516 & 30 & 18 \\
& 156 & 9 & 18 \\
& 93.4 & 5.5 & 11
\end{tabular}

the coefficients of variation throughout the range of concentration of $\gamma$ globulin were constant and a value pooled from all the data was $13 \%$. For the inhibition of antiglobulin serum technique, the coefficient of variation does not vary consistently with the concentration; the pooled value is $13 \%$.

Unfortunately, there was not enough material available for a similar study of the error of electrophoretic measurements to be made. However, four estimations were made on a pool of normal serum and on each of a series of mixtures of purified albumin and $\gamma$ globulin (fractions AP3 and G4 of Kekwick and Mackay, 1954). The albumin concentrations of these mixtures were maintained constant at a level corresponding to that obtained when normal human serum was diluted for electrophoretic examination, as described previously. The $\gamma$ globulin content of the mixtures was varied to correspond with serum contents of 50,100 , and $200 \mathrm{mg} . / 100 \mathrm{ml}$. The results are shown in Table II.

These errors show no consistent relationship to concentration but the scatter shown in Fig. 2 is larger than could be expected from the application

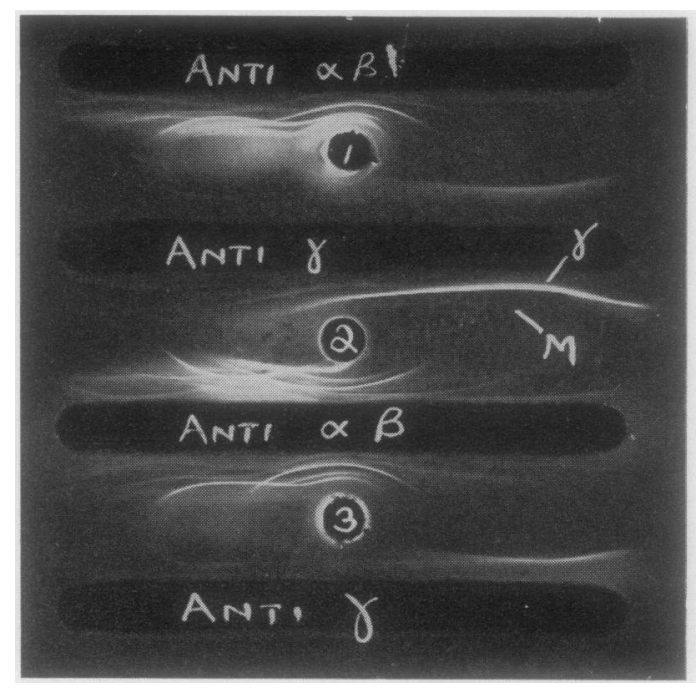

FIG. 3. Immunoelectrophoresis of serum from a healthy adult male (2) and from two patients with hypogamma- $\frac{}{8}$ globulinaemia, one probably of the congenital type (1) and one probably of the acquired type (2) reacting with $a \overrightarrow{\vec{\theta}}$ rabbit anti-human $\gamma$ globulin antiserum typical of the ones used for the gel diffusion precipitin technique, and with a rabbit antiserum containing antibodies against many human globulins, but with little or no anti-albumin or anti- $\gamma$ globulin. The $\gamma$ globulin precipitin line (labelled $\gamma$ ), elongated as compared with those due to the other serum proteins in normal serum, is deficient in sera 1 and $3 . \stackrel{\circ}{1}$ The line of the 19S component of $\gamma$ globulin (identical with the $\beta_{2} M$ of continental workers), labelled $M$, which is $\overline{\bar{O}}$ shown by both antissra, is present in sera 2 and 3 , but 3 absent in serum 1 .

of these estimates. It seems likely, therefore, that there is a difference in the nature of the material estimated by each of the techniques.

NATURE OF PROTEIN ESTIMATED BY EACH TECHNIQUE Gamma globulin is defined as the slowest moving component observed during the electrophoresis of $\frac{0}{5}$ human serum by the moving boundary method at $\frac{D}{O}$ slightly alkaline $p H$ values. It is definitively estimated from the area of the peak produced by the $N$ application of Schlieren optical methods or by

TABLE II

RESULTS OF EXPERIMENTS TO DETERMINE ERROR OF ESTIMATION OF $\gamma$ GLOBULIN BY ELECTROPHORESIS

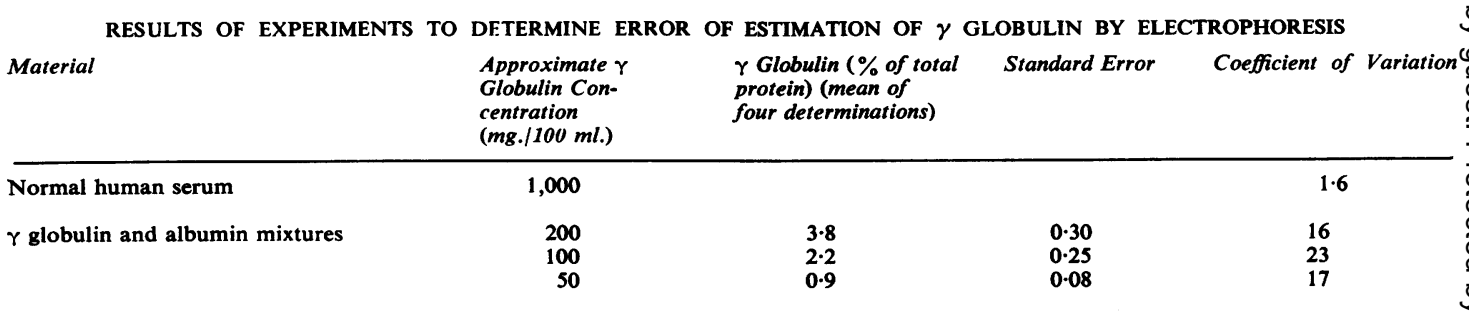


interferometric procedures. Other methods of estimating it must clearly be substantiated by comparison with electrophoretic estimations.

In patients with hypogammaglobulinaemia, the substance of practical importance is antibody protein, and though this is known to be associated predominantly with $\gamma$ globulin in man, there is evidence to suggest that antibody activity may be associated with components of greater electrophoretic mobility. Gamma globulin is electrochemically heterogenous; moreover, it includes a protein whose sedimentation coefficient is $19 \mathrm{~S}$, as well as the predominant $7 \mathrm{~S}$ component.

The electrochemical heterogeneity of $\gamma$ globulin is well illustrated by immunoelectrophoresis. In Fig. 3, the anti $\gamma$ globulin antiserum used for the gel diffusion estimations and an antiserum against a wide range of human $\alpha$ and $\beta$ globulins are shown interacting with normal human serum and with sera from two patients with hypogammaglobulinaemia. The $\gamma$ globulin precipitin line in normal serum is longer and straighter than the precipitin lines for other proteins, most of which are symmetrical arcs (Grabar and Burtin, 1960). This results from the fact that $\gamma$ globulin molecules have a wide range of electrophoretic mobility. It will be seen that there is material reacting with the same antibody stretching well forward into the $\beta$ and $\alpha$ positions. This material is not $\gamma$ globulin, as defined electrophoretically above, but it may be antibody protein. There is no doubt that the gel diffusion precipitin technique estimates all of the protein thus antigenically defined.

The 19S component of the electrophoretically defined $\gamma$ globulin is antigenically distinct from the $7 \mathrm{~S}$ component, and though antibody to it is present in some of the antisera used for estimating $\gamma$ globulin by the gel diffusion technique (see Fig. 3), this would form a separate precipitin line and would be diluted out, so that it does not affect the estimation of the 7S component. Specific antisera to this protein (also called $\beta_{2} \mathrm{M}$ ), which is often deficient in serum of patients with hypogammaglobulinaemia (Gitlin, Hitzig, and Janeway, 1956), can be used to estimate it by the gel diffusion technique (see later).

The specificity of the inhibition of antiglobulin serum technique does not depend on the specificity of the antiserum used, which may contain antibodies against many human serum proteins. The specificity of the test depends upon the fact that only protein which is antigenically identical with $\mathrm{Rh}$-antibody protein will inhibit the reaction between antiglobulin serum and $\mathrm{Rh}$-sensitized red cells. There is evidence that incomplete anti-Rh is a $7 \mathrm{~S} \gamma$ globulin (Fudenburg, Kunkel, and Franklin, 1959) and it seems likely that the interaction of this protein with anti- $\gamma$ globulin will be inhibited by all the ' $\gamma$ globulin' demonstrated by immunoelectrophoresis to interact with antibody to 7S $\gamma$ globulin (see Fig. 3).

Probably therefore the two immunological techniques are estimating the same substance, that is to say, all the protein of the line marked ' $\gamma$ ' in Fig. 3. As already mentioned, this includes some protein with the mobility of $\alpha$ and $\beta$ globulins which will not be included in an electrophoretic estimate of $\gamma$ globulin. On the othar hand, it will not include $19 \mathrm{~S}$ $\gamma$ globulin, marked ' $M$ ' in Fig. 3, some of which will be included in an electrophoretic estimate.

Slater (1955) estimated the $\gamma$ globulin content of samples of human serum by a precipitin method using an anti- $\gamma$ globulin serum and found that with normal sera and sera containing an abnormally large amount of $\gamma$ globulin, the immunological estimates were 20 to $40 \%$ higher than electrophoretic estimates on the same samples. This presumably represented the difference between total ' $7 \mathrm{~S}$ antibody protein' (immunological technique) and electrophoretically defined $\gamma$ globulin, i.e., part of the 7S + part of the 19S. There is, however, no direct evidence that the whole of the proteins defined antigenically as ' $7 \mathrm{~S}$ ' is potential antibody or is, in fact, $7 \mathrm{~S}$.

In view of Slater's findings, the apparent agreement in the present work between estimates by immunological techniques and by electrophoresis needs explanation. So far as the inhibition of the antiglobulin serum method is concerned, the explanation seems to be provided by the fact that whole human serum rather than $\gamma$ globulin was used as a standard, and it was in fact shown that if $\gamma$ globulin were used as a standard, the ' $\gamma$ globulin' content of normal human serum was overestimated. Thus Table III shows the results of tests on three normal

\section{TABLE. III}

$\gamma$ GLOBULIN CONCENTRATION OF THREE NORMAL SERA AND ONE PREPARATION OF $\gamma$ GLOBULIN (LKG.11) USING ANOTHER $\gamma$ GLOBULIN PREPARATION (G.4) AS A REFERENCE STANDARD

\begin{tabular}{lcc} 
Sample & \multicolumn{2}{l}{$\begin{array}{l}\text { Estimate of } \gamma \text { Globulin Concentration } \\
(\mathrm{mg} / 100 \mathrm{ml} .)\end{array}$} \\
\cline { 2 - 3 } & $\begin{array}{l}\text { Inhibition of Anti- } \\
\text { globulin Serum }\end{array}$ & $\begin{array}{l}\text { Free } \\
\text { Electrophoresis }\end{array}$ \\
\hline Normal serum (M.C.) & 2,020 & 1,155 \\
Normal serum (J.F.S.) & 1,270 & 970 \\
Normal serum (G.C.J. & 1,640 & 1,270 \\
$\gamma$ globulin (LKG. 11) & 900 & 930
\end{tabular}

sera and two preparations of purified $\gamma$ globulin. Using one of the $\gamma$ globulin preparations as a standard, the amount of $\gamma$ globulin in the other $\gamma$ globulin preparation was correctly estimated. But estimates for the $\gamma$ globulin concentration of the three normal sera were all far too high in comparison 
with the estimates obtained by electrophoresis (see Table III). Thus agreement with electrophoresis is obtained by this technique only when whole serum, which has had its $\gamma$ globulin content defined by electrophoresis, is used as a standard. Where electrophoretically faster moving antibody protein and the $19 \mathrm{~S}$ component of $\gamma$ globulin vary pari passu with the 7S component agreement with electrophoresis will he obtained. When a purified $\gamma$ globulin standard is used the result presumably represents total 7S antibody protein.

For the gel diffusion precipitin technique purified $\gamma$ globulin was used as a standard and it is therefore difficult to see why estimates obtained with this technique were not greater than those obtained by electrophoresis.

Immunoelectrophoresis shows that in hypogammaglobulinaemia sera the whole of the $7 \mathrm{~S}$ antibody protein line is deficient; in fact there is only a faint line visible with a mobility corresponding to the centre of the line present in normal sera, that is, to the position where the concentration is usually greatest. Therefore, a discrepancy between the techniques due to the electrochemical heterogeneity of $\gamma$ globulin is likely to be in the direction of a systematic bias rather than an increased scatter of results.

Nevertheless, a discrepancy between electrophoresis and immunological estimates could arise from variations in the relative amounts of other proteins, e.g., 19S $\gamma$ globulin, if this does not vary proportionally with 7S $\gamma$ globulin. This situation was observed in three patients in our series, and it may well explain some of the excessive scatter in the results obtained in parallel estimations of the sera from individual patients by the electrophoretic and the immunological techniques.

Estimation of the serum $\gamma$ globulin of two of these (G.B. and N.B.) by electrophoresis gave consistently higher results than by the two immunological techniques, as shown in Table IV. And in the third (C.B.) paper electrophoresis of serum gave an apparently normal $\gamma$ globulin band, though the gel

\section{TABLE IV}

RESULTS OF ESTIMATIONS OF $\gamma$ GLOBULIN ON SERA FROM TWO PATIENTS WITH HYPOGAMMAGLOBULINAEMIA

\begin{tabular}{lcccc} 
Patient & Date & $\begin{array}{l}\text { Electro- } \\
\text { phoresis } \\
(\mathrm{mg} . / 100 \mathrm{ml} .)\end{array}$ & $\begin{array}{l}\text { Inhibition of } \\
\text { Antiglobulin } \\
\text { Serum } \\
(\mathrm{mg} . / 100 \mathrm{ml} .)\end{array}$ & $\begin{array}{l}\text { Gel Diffusion } \\
\text { Precipitin } \\
(\mathrm{mg} . / 100 \mathrm{ml} .)\end{array}$ \\
\hline G.B. & 19.9 .56 & 285 & $17 \cdot 5$ & 10 \\
& 19.12 .56 & 315 & 300 & 120 \\
N.B. & 25.1 .57 & 233 & 25 & 35 \\
& 14.3 .57 & 320 & 160 & 140 \\
& 25.4 .58 & 400 & - & 280
\end{tabular}

diffusion precipitin method showed grossly depleted $\gamma$ globulin. Thus in all these three cases electrophoretic estimates were higher than those obtained 0 by immunological techniques. It was shown that these three cases were the only ones (out of the 41 studied) in whose sera the 19S component of $\gamma \overrightarrow{\mathbb{D}}$ globulin was not greatly reduced in concentration. It has previously been shown by immunochemical methods that the 19S component of $\gamma$ globulin is one of the other two serum proteins besides the main $7 \mathrm{~S} \gamma$ globulin component which are deficient in most patients with hypogammaglobulinaemia (Gitlin et $\vec{?}$ al., 1956). In two of these three patients, the $19 \mathrm{~S}$ component was estimated by the gel diffusion of precipitin technique only, but in the third an ultra- $A$ centrifugal analysis was also made. The serum of $d$ patient N.B. had a normal concentration of $50 \mathrm{mg}$./ 을 $100 \mathrm{ml}$; that of G.B. had an abnormally high concentration of $100 \mathrm{mg} . / 100 \mathrm{ml}$; C.B. had the $\mathbb{D}$ remarkably high concentration of $500 \mathrm{mg} . / 100 \mathrm{ml}$. This boy (C.B.) who will be reported in detail else- $\frac{\mathbb{D}}{3}$ where (Bodian, Marshall, and Weston, 1961) presented with Pneumocystis carinii pneumonia which led to the suspicion of hypogammaglobulinaemia. $\vec{\oplus}$ On paper electrophoresis the $\gamma$ globulin concentration was normal, but an estimate by the gel 0 diffusion precipitin technique gave a result of only $35 \mathrm{mg} . / 100 \mathrm{ml}$. Ultracentrifugal analysis showed that there was a normal $4.5 \mathrm{~S}$, but no $7 \mathrm{~S}$ component detectable and also confirmed that the 19S com- $\mathbb{D}$ ponent was increased $(670 \mathrm{mg} . / 100 \mathrm{ml}$.). This $\stackrel{2}{\Rightarrow}$ includes the 19S $\alpha_{2}$ glycoprotein of presumably normal concentration (about $150 \mathrm{mg} . / 100 \mathrm{ml}$.). Unfortunately, there was not enough serum for Tiselius electrophoresis but an estimate by paper electrophoresis (kindly performed by Dr. J. Hardwicke) gave a figure for the $\gamma$ globulin concentration of $960 \mathrm{mg} . / 100 \mathrm{ml}$. The excess $19 \mathrm{~S}$ component accounts for much of the discrepancy, which would probablyo have arisen also with Tiselius electrophoresis. The $7 \mathrm{~S}$ component of $\gamma$ globulin is often low in macro-음 globulinaemia, but this patient showed no other $>$ features of this disease. The ' $\gamma$ globulin' by electrophoresis on paper was indistinguishable from that of a normal child of this age.

APPLICATION TO THE DIAGNOSIS OF HYPOGAMMAGLOBULINAEMIA Some $\gamma$ globulin was detected ing the serum of all 61 patients with hypogammaro globulinaemia studied by the M.R.C. working party, $\overparen{\mathbb{\Phi}}$ so that a quantitative estimate was required for $\stackrel{\oplus}{+}$ making the diagnosis. In one, no $\gamma$ globulin was? detected by the gel diffusion precipitin technique, $\vec{O}$ for which the lowest limit of detection is $0.06 \mathrm{mg}$.

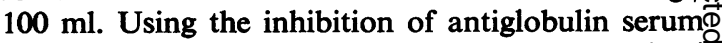
method, slight but definite inhibition was obtainedo 
with the patient's undiluted serum and, by comparison with suitable dilutions of whole human serum, it was estimated that the $\gamma$ globulin concentration was about $0.1 \mathrm{mg} . / 100 \mathrm{ml}$.

Techniques routinely available at present in laboratories for estimating $\gamma$ globulin are the zinc sulphate precipitation method (Kunkel, 1947) and paper electrophoresis. These are not sensitive at low concentrations of $\gamma$ globulin. The zinc sulphate method gives little precipitation at the normal concentrations, and is really suitable only for abnormally high $\gamma$ globulin concentrations. Paper electrophoresis estimation of the electrophoretic protein fractions has an error of about $6 \%$ of the total protein concentration (Hardwicke, 1954). In the sera studied this would amount to about $360 \mathrm{mg}$. $/ 100 \mathrm{ml}$., so that it is unsatisfactory for estimating $\gamma$ globulin at concentrations less than $200 \mathrm{mg} . / 100 \mathrm{ml}$. It is, however, a useful screening procedure. Provided that cases in which it may be misleading, such as C.B. described above, are borne in mind, an obvious and distinct $\gamma$ globulin band on paper electrophoresis usually excludes the diagnosis of hypogammaglobulinaemia. But any serum in which the $\gamma$ globulin band is at all indistinct requires investigation by other techniques.

Our results show that any one of the techniques studied by us is satisfactory for routine clinical use for the diagnosis of hypogammaglobulinaemia. However, they are not all practicable for a routine laboratory.

Electrophoresis has the advantage of being independent of standards. But, at low concentrations, it is not as sensitive as the other methods, and a single estimation takes a day to perform and requires an expensive apparatus not generally available.

The antiglobulin inhibition technique is probably the most sensitive of the methods studied. Moreover, all the reagents needed were readily available and almost any antiglobulin serum is suitable. On the other hand, the method is somewhat time-consuming, a batch of up to four estimations taking about three hours.

The gel diffusion precipitin technique, because of its logarithmic error (the standard deviation is about $13 \%$ of the concentration), is relatively insensitive at high concentrations, though this is no disadvantage when estimating a protein deficiency. It is quick and easy and is economical of the antiserum, which need not be completely specific.

\section{REFERENCES}

Bodian, M., Marshall, W. C., and Weston, H. J. (1961). Peroalns communication.

Coombs, R. R. A., and Mourant, A. E. (1947). J. Path. Bact., 59, 105.

Freund, J., and McDermott, K. (1942). Proc. Soc. exp. Biol. (N.Y.), 49, 548.

Fudenburg, H. H., Kunkel, H. G., and Franklin, E. C. (1959). Proc. 7th Congr. Int. Soc. Blood Trans., Rome 1958, Bibliotheca haematologica (Fasc. 10), p. 522.

Gell, P. G. H. (1957). J. clin. Path., 10, 67.

Gitlin, D., Hitzig, W. H., and Janeway, C. A. (1956). J. clin. Invest., 35, 1199.

Grabar, P., and Burtin, P. (1960). Analyse Immuno-Electrophorétique Masson, Paris.

Grubb, R. (1956). Acta path. microbiol. scand., 38, 339.

Hardwicke, J. (1954). Biochem. J., 57, 166.

Kekwick, R. A., and Mackay, M. E. (1954). Spec. Rep. Ser. med. Res. Coun. (Lond.), No. 286.

Kunkel, H. G. (1947). Proc. Soc. exp. Biol. (N.Y.), 66, 217.

Mollison, P. L. (1956). Blood Transfusion in Clinical Medicine, 2nd ed., p. 310. Blackwell, Oxford.

Perlmann, G. E., and Longsworth, L. G. (1948). J. Amer. chem. Soc., 70, 2719.

Philpot, J. St. L. (1938). Nature (Lond.), 141, 283.

Slater, R. J. (1955). Arch. Biochem. Biophys., $59,33$.

Wiener, A. S. (1955). Amer. J. clin. Path., 25, 595.

-, Hyman, M. A., and Handman, L. (1949). Proc. Soc. exp. Biol. (N.Y.), 71, 96. 